\title{
Development of Russian food export capacity under external constraints
}

\author{
I. F. Suhanova ${ }^{1 *}, M$. Yu. Lyavina, and I. S. Ismailov
}

Saratov state agrarian University named after N. I. Vavilov, 410012, 1, Theatre sq., Saratov, Russian Federation

\begin{abstract}
The article represents the level of development of the Russian food export capacity. The factors influencing the country's food system have been systematised. The food export and import performance has been analysed. The self-sufficiency in essential food products has been assessed. The need for development of food export capacity under external restrictions has been substantiated. The directions of Russia's food export capacity development have been highlighted.
\end{abstract}

\section{Introduction}

Foreign economic activity is crucial for the development of the national economy at the current juncture. It is foreign economic activity that is becoming more significant factor determining the national social and economic processes.

The Existing economic sanctions cause macroeconomic instability, followed by a sharp fall of the rouble (more than twice in 2020 as contrasted with March 2014), rising food prices, a significant fluctuation in the CBR key rate, extremely limited fixed asset investment and a loss of Russian consumer's purchasing power [1]. These factors determine the state of the economy and food system of Russia. The coronavirus pandemic is a major factor making it more difficult to ensure food security. It shocked the modern world food market, changed its general price, qualitative and quantitative values, and also affected the development of the Russian agricultural economics and food export capacity.

The Russian import substitution policy should build food export capacity providing for active export policy, supported by economic diplomacy, internal institutional measures as well as integrated tariff, tax and currency mechanism. This is especially important for agricultural production having significant export capacity. What is meant here is the need for a substantial expansion of both the commodity and geographical structure of foreign economic relations at the federal and regional levels as well as manifold increase of food and agricultural stock export.

The practical aspects of the establishment and development of the food export capacity of the Russian Federation are highly significant in the context of the country's integration into the global food system [2]. The development and application of strategies for the food export capacity development are relatively new both for foreign economic activity participants and for agricultural sector authorities [3]. The effective application of various

*Corresponding author: suhanovaif@sgau.ru 
measures for the food export capacity development at the national and regional levels requires involvement of highly professional foreign economic activity specialists, as well as targeted funding [4].

The work sets an objective to analyse the current food export capacity and determine its development directions under the external constraints.

\section{Methods}

The study is based on information analytical findings, statistical data provided by the Federal State Statistics Service and the Ministry of Agriculture of the Russian Federation, and information from the Internet.

The agricultural sector of the Russian Federation has been tasked with increasing the volume of exports to USD 45 billion by 2024.

In order to ensure sustainable development of the agricultural sector and firm entry into foreign markets a national project "International Cooperation and Exports" (approved by the Presidium of the Russian Presidential Council for Strategic Development and National Projects, Minutes No. 16 dated December 24, 2018) was developed which includes the Federal Project "Export of Agricultural Products" [5].

The key objectives of the national project "International Cooperation and Export" include increase of non-resource non-energy goods exports, increase of the share of manufactured products, agricultural products and services exports in the gross domestic product, establishment of an effective system of division of labour and industrial cooperation within the Eurasian Economic Union in order to increase the trade between the Union members and ensure growth in cumulative mutual investments.

The main tasks of the Federal Project "Export of Agricultural Products" are as follows:

Task 1 "To create a new commodity weight of agricultural products, including high value-added goods through technological re-equipment of the industry and other supporting measures."

Task 2 "To create an export-oriented commodity-distribution infrastructure."

Task 3 "To eliminate trade barriers (tariff and non-tariff) in order to ensure access of agricultural products to target markets."

Task 4 "To create a promotion and marketing system for agricultural products."

The solution of the set tasks depends on developed food export capacity $[6,7]$ as well as on comprehensive food market analysis, flow of food demand in foreign regions and countries, assessment of the current geographical and commodity structure of agricultural exports, SWOT analysis of certain industries, identification of food market segments advantageous for product supply, demanded product groups and individual products as well as substantiation of the directions of agricultural exports diversification.

This project enables agricultural goods producers to integrate into the world food system, increase export supplies and the country's food export capacity.

\section{Results and discussion}

The study has found that the growth of national output in the agricultural sector made it possible to increase the share of domestic agricultural products in the domestic food market as well as export supplies. The export/import cover rate remains upward and is constantly growing (see the figure below). 


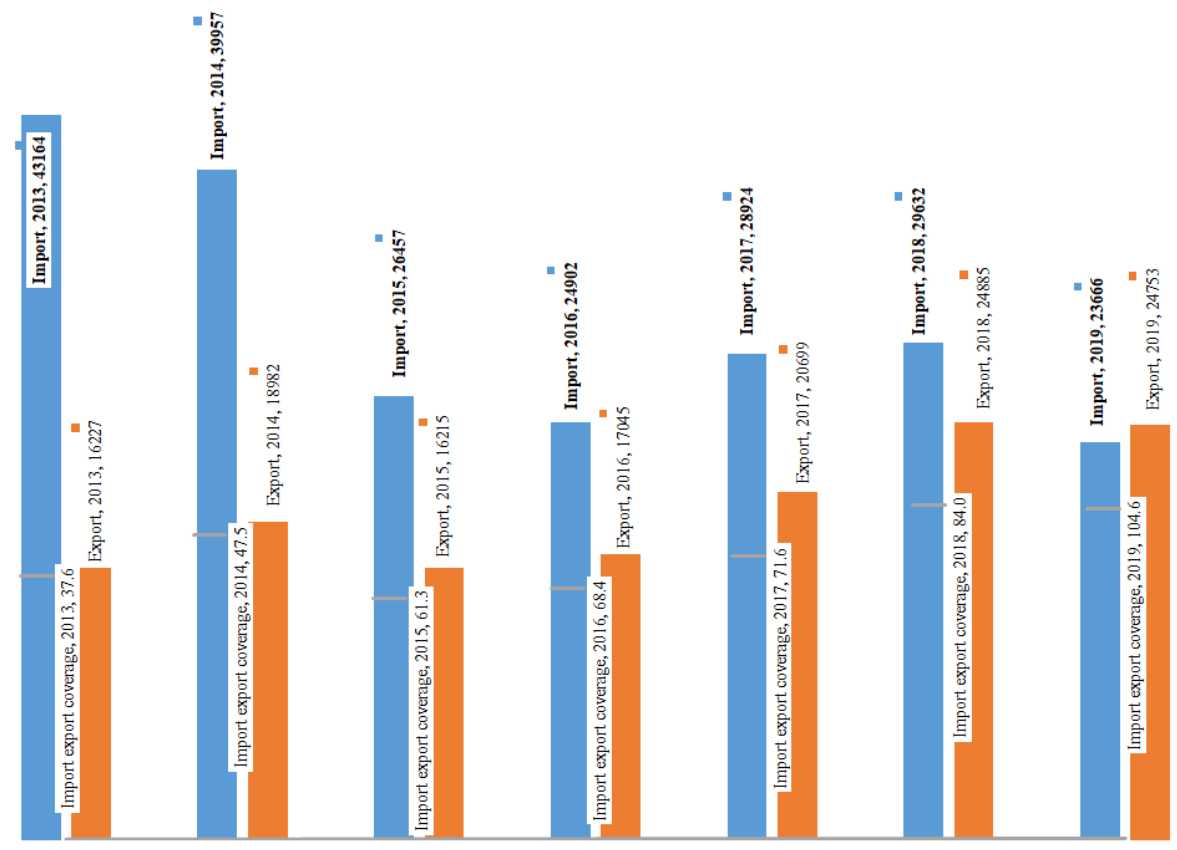

Fig. Trends in foreign trade in food and agricultural products, USD mln [8].

The main trend in foreign economic activity is a decrease in imports with simultaneously increasing exports. The analysis of trends in the share of certain goods imports in retail commodity resources has revealed that meat and poultry imports decreased from $13.4 \%$ in 2015 to $7.3 \%$ in January-September 2019. Over the same period, the imports of beef, including by-products, decreased from $48.1 \%$ to $36.1 \%$, pork imports from $12.5 \%$ to $3 \%$ [9].

However, at year-end 2018, the required self-sufficiency was not achieved in terms of milk, potatoes, vegetables and melons and gourds, salt, fruits and berries. The share of Russian milk was $83.9 \%$ against the required $90 \%$. The salt indicator is even lower, $64.2 \%$ (threshold level is $85 \%$ ). The provision of Russia's population with home-grown vegetables, melons and gourds is at $87.2 \%$, provision with fruits and berries is at $38.8 \%$. The share of butter imports in the commodity resources for 9 months of 2019 was $26.6 \%$, milk powder and dairy cream share reached $39.4 \%$. [9]

Regardless of the decreased share of imports in the Russian food market, there is a strong resource and production dependence on imports, especially in terms of food products manufacturing. The agricultural imports in domestic business turnover (products expenses in the industry) reached $7.6 \%$, the food industry imports was $19.6 \%$. The import intensity of the total industries output was as follows: $3.8 \%$ in agriculture, $9.5 \%$ in the food industry. The imports in the used agricultural resources are at $11.6 \%$ and $14.4 \%$ in food and beverage products. The represented data supports the conclusion about high dependence on resources.

The economic sanctions have revealed high import dependence of the national agricultural sector as per a number of intermediate goods and high-end technologies. Specifically, in crop farming some crops (maize, vegetables, sugar beets and sunflower) involve $50 \%$ - 90\% of imported seeds [10]. In animal farming, more than $50 \%$ of premixes, feed additives, as well as breeding animals are imported. The high resource and production dependence of domestic agricultural production in terms of material and technical supplies (machinery and equipment) should be noted. Notwithstanding that the Russian Federation 
is currently one of the major producers and exporters of grain and is self-sufficient in bakery products, most of the bread making process is provided using imported production tools.

Despite the fact that currently, a large share of imported food products in domestic markets tends to decline due to of the embargo, import intensity in terms of resources or production remains high. The issue of high import intensity of food manufacturing should be designated as external economic challenges impeding the development of food export capacity.

The monitoring of export-import activity makes it possible to specify priorities for building and development of Russia's food export capacity under external constraints (see the table below).

Table. Priorities for the Russia's food export capacity development.

\begin{tabular}{|l|l|l|}
\hline \multicolumn{1}{|c|}{ Segment } & \multicolumn{1}{|c|}{ Products } & Direction of sales geography diversification \\
\hline I. Grain segment & Grain & India, Sri Lanka, Philippines and Indonesia \\
\hline \multirow{4}{*}{ II. Meat segment } & Turkey & $\begin{array}{l}\text { Africa } \\
\text { Vietnam and Hong Kong } \\
\text { Serbia and EU countries } \\
\text { Middle East }\end{array}$ \\
\cline { 2 - 3 } & Pork & China \\
\cline { 2 - 3 } & Chicken & $\begin{array}{l}\text { Asian countries } \\
\text { CIS countries } \\
\text { African countries }\end{array}$ \\
\hline $\begin{array}{l}\text { III. Segment of oil-bearing } \\
\text { plants and vegetable oils }\end{array}$ & Sunflower oil & $\begin{array}{l}\text { EU countries } \\
\text { China }\end{array}$ \\
\hline \multirow{3}{*}{$\begin{array}{l}\text { IV. Feed and product } \\
\text { processing waste segment }\end{array}$} & Feed & $\begin{array}{l}\text { Asia } \\
\text { product } \\
\text { processing } \\
\text { waste }\end{array}$ \\
\hline
\end{tabular}

\section{Conclusion}

International economic relations currently include not only the exchange of raw materials and finished products, but other stages of the reproductive process as well. In this regard, the effective development of agricultural sector should rely not only on increasing export supplies, but also on updating products offered in the world market. What is meant here is diversification of agricultural enterprises exports. Integration into the uniform global food system may be managed under different conditions, determined by the developed export capacity and current competitive strengths. From this perspective, there is a need to develop a relevant business mechanism for the development of the food export capacity of the Russian Federation, stimulating international competitiveness of the agricultural sector and market positioning of the country in the overall international business relationship.

\section{References}

1. I. L. Vorotnikov, I. F. Sukhanova, M. Yu. Lyavina, M. I. Glukhova, K. A. Petrov, Entrepreneurship and Sustainability Issues, 6, 4 (2019)

2. I. F. Sukhanova, Agrarian Scientific Journal, 3 (2009)

3. N. Yu. Mukhin, Russian Foreign Economic Journal, 2 (2016)

4. I. F. Sukhanova, M. Yu. Lyavina, Russia's food import substitution in the face of external challenges and restrictions (2017) 
5. Federal Project "Export of Agricultural Products" APPROVED by the Presidium of the Council at The President of the Russian Federation on Strategic Development and Priority Projects dated November, 30, 11 (2016)

6. S. I. Gorbunov, I. F. Sukhanova, M.Yu. Lyavina, The Journal of Social Sciences Research, Special Issue, 3 (2018)

7. N. A. Yakovenko, I. A. Rodionova, I. S. Ivanenko, N. A. Kireeva, A. M. Sukhorukova, International Journal of Engineering and Technology (UAE), 7, 4 (2017)

8. Russian Federal State Statistics Service, Publications catalogue (2021)

9. Russian Federal State Statistics Service. Indicators characterizing import substitution in Russia (2021)

10. Russia's food import substitution in the face of external challenges and restrictions (2021) 